\title{
Phosphoinositide kinase activities in synaptosomes prepared from brains of patients with Alzheimer's disease and controls
}

Citation for published version (APA):

Bothmer, J., Markerink, M., \& Jolles, J. (1994). Phosphoinositide kinase activities in synaptosomes prepared from brains of patients with Alzheimer's disease and controls. Neuroscience Letters, 176(2), 169-172. https://doi.org/10.1016/0304-3940(94)90074-4

Document status and date:

Published: 01/01/1994

DOI:

10.1016/0304-3940(94)90074-4

Document Version:

Publisher's PDF, also known as Version of record

Please check the document version of this publication:

- A submitted manuscript is the version of the article upon submission and before peer-review. There can be important differences between the submitted version and the official published version of record.

People interested in the research are advised to contact the author for the final version of the publication, or visit the DOI to the publisher's website.

- The final author version and the galley proof are versions of the publication after peer review.

- The final published version features the final layout of the paper including the volume, issue and page numbers.

Link to publication

\footnotetext{
General rights rights.

- You may freely distribute the URL identifying the publication in the public portal. please follow below link for the End User Agreement:

www.umlib.nl/taverne-license

Take down policy

If you believe that this document breaches copyright please contact us at:

repository@maastrichtuniversity.nl

providing details and we will investigate your claim.
}

Copyright and moral rights for the publications made accessible in the public portal are retained by the authors and/or other copyright owners and it is a condition of accessing publications that users recognise and abide by the legal requirements associated with these

- Users may download and print one copy of any publication from the public portal for the purpose of private study or research.

- You may not further distribute the material or use it for any profit-making activity or commercial gain

If the publication is distributed under the terms of Article $25 \mathrm{fa}$ of the Dutch Copyright Act, indicated by the "Taverne" license above, 


\title{
Phosphoinositide kinase activities in synaptosomes prepared from brains of patients with Alzheimer's disease and controls
}

\author{
John Bothmer*, Marjanne Markerink, Jellemer Jolles \\ Department of Psychiatry and Neuropsychology, Section NNP, University of Limburg, PO Box 616, 6200 MD Maastricht, The Netherlands
}

Received 18 April 1994; Revised version received 6 June 1994; Accepted 6 June 1994

\begin{abstract}
Previously, phosphatidylinositol (PI) kinase activity in cytosolic fractions prepared from postmortem tissue of the cerebral cortex from patients with Alzheimer's disease (AD) appeared to be lower than that of age-matched controls [Jolles et al., J. Neurochem., 58 (1992) 2326-2329]. In the study presented here, PI and PIP (phosphatidylinositol phosphate) kinase activities were studied in synaptosomes prepared from postmortem brain tissue of AD patients and age-matched controls. Firstly, PI kinase activity in synaptosomes prepared from the frontal superior gyrus of AD brain was $30 \%$ lower than in synaptosomes prepared from postmortem tissue of control brain. PIP kinase activity was the same in AD and control synaptosomes. Secondly, the yield of synaptosomal protein ( $\mu \mathrm{g}$ protein per mg tissue wet weight) was lower in preparations from AD brain than in preparations from control brain, which could be a manifestation of a loss of presynaptic terminals in the frontal cortex. These results suggest that the difference in PI kinase activity between AD and control brain tissue may originate from differences in intact neurons in view of the fact that synaptosomes can originate only from intact neurons.
\end{abstract}

Key words: Phosphatidylinositol; Phosphatidylinositol phosphate; Kinase; Alzheimer's disease; Brain cortex; Synaptosome

Alzheimer's disease (AD) is characterized by the occurrence of neuritic plaques and neurofibrillary tangles. The mechanism by which these protein deposits are formed is still not known and is, therefore, subject to investigation by many researchers. However, besides these characteristics, there is growing evidence that $\mathrm{AD}$ is also characterized by a decline in the functional integrity of receptor-mediated signal transduction [9]. The metabolism of phosphoinositides could play a central role in these changes as phosphoinositides are involved in different signal transduction pathways [3]. Phosphatidylinositol 4,5-bisphosphate $\left(\mathrm{PIP}_{2}\right)$ is thought to be hydrolyzed by phospholipase C (PLC) into the second messengers inositol trisphosphate and diacylglycerol after G-protein-intermediated receptor stimulation [1]. Furthermore, the recently discovered D-3 phosphorylated phosphoinositides seem to be involved in cell proliferation [19], and in the cytoskeletal rearrangements that

*Corresponding author. Fax: (31) (43) 671096. occur during the mitotic cell cycle and in postmitotic cells during exocytosis [8].

In $\mathrm{AD}$ brain, the concentration of phosphoinositides is lower than in brains from age-matched controls [23]. The PLC isozyme PLC- $\delta$ is found to be abnormally accumulated in neurofibrillary tangles, the neurites surrounding senile plaque cores, and neuropil threads in $A D$ brains. Moreover, diffuse and amorphous deposits of PLC- $\delta$ were found to precede the accumulation of fibrillary deposits. The other PLC isozymes were not found to be abnormally accumulated [22]. The number of binding sites for the product of PLC activity, inositol trisphosphate which is essential for calcium release, is severely reduced $(50-70 \%)$ in the temporal cortex and hippocampus of AD brains [24]. Furthermore, Jolles et al. [14] have shown that AD brains (neocortex) have a reduced cytosolic PI kinase activity. In addition, it seems that just one type of PI kinase, type 1 PI kinase or PI 3-kinase, is affected in AD [5]. Type 1 PI kinase is involved in growth factor signalling, cell proliferation and regulation of the turnover of the cytoskeleton [6]. Interestingly, neurofibrillary tangles, which are a prominent 
feature of $\mathrm{AD}$, are partially composed of wrongly metabolized cytoskeletal components [10].

Until now, the difference in PI kinase activity between $\mathrm{AD}$ and control brains has been found in protein preparations without an intact cellular structure. Therefore, the difference in PI kinase activity could be caused by an overall effect related to cell death, which occurs late in the cascade of events underlying the pathogenesis of AD. However, a decreased PI kinase activity in intact brain cells from $\mathrm{AD}$ brain would be a strong indication that this phenomenon occurs early in the cascade of events. Therefore, the present study was designed to provide information about phosphoinositide (PI and PIP) kinase activities in intact synaptosomes prepared from the frontal cortex of $\mathrm{AD}$ and control brains.

Brain samples from six AD patients (four males and two females; mean age 67 years) and six controls (four males and two females; mean age 64 years) were used in this study. The brains were individually matched for age and postmortem interval with brain tissue obtained from the Netherlands Brain Bank (Coordinator: Dr. R. Ravid). The mean postmortem interval was $4 \mathrm{~h} 40 \mathrm{~min}$ for the AD patients and $5 \mathrm{~h} 50 \mathrm{~min}$ for the controls $(P>0.1$; Student's $t$-test). The AD patients had been clinically diagnosed as 'probable Alzheimer's disease' and this was verified by postmortem neuropathological examination. The controls were individuals without a history of dementia, or any other neurological or psychiatric disorder.

Brain specimens for analysis of inositol phospholipid kinase activity were obtained from the frontal superior gyrus. The leptomeninges were removed and samples were excised. These samples were sealed in plastic, rapidly frozen by immersion in liquid nitrogen, and stored at $-80^{\circ} \mathrm{C}$ until use.

After thawing in a water bath at $0^{\circ} \mathrm{C}$, the tissue was homogenized in $0.32 \mathrm{M}$ sucrose, $1 \mathrm{mM}$ EDTA, $10 \mathrm{mM}$ Tris- $\mathrm{HCl}, \mathrm{pH} \mathrm{7.4,} \mathrm{in} \mathrm{a} \mathrm{total} \mathrm{volume} 10$ times the brain tissue volume by 12 up-and-down strokes of a PotterElvehjem Teflon-glass homogenizer (radial clearance $0.125 \mathrm{~mm}, 700 \mathrm{rpm}$ ). The homogenate was centrifuged at $1300 \times g$ for $5 \mathrm{~min}$. After centrifugation of the supernatant at $17,000 \times g$ for $14 \mathrm{~min}$, the resulting crude mitochondrial-synaptosomal pellet was resuspended in homogenization buffer and then applied to a discontinous Ficoll-sucrose gradient as described earlier $[2,15]$. The tubes were centrifuged at $100,000 \times g$ for $45 \mathrm{~min}, 4^{\circ} \mathrm{C}$. Myelin and synaptosomes banded at the first and second interphases, respectively, with the free mitochondria being pelleted at the bottom. The synaptosomal layer was carefully removed and suspended in homogenization buffer. After centrifugation $\left(11,000 \times g, 15 \mathrm{~min}, 4^{\circ} \mathrm{C}\right)$, the synaptosomal pellet was resuspended in hypotonic phosphate buffer (20 mM, pH 7.4). This fraction was stored at $-80^{\circ} \mathrm{C}$.

Phosphatidylinositol (PI) and phosphatidylinositol phosphate (PIP) kinase activities were measured as described earlier [5]. Aliquots of lysed synaptosomes (15 $\mu$ ). 10-20 $\mu$ g protein) were preincubated for $2 \mathrm{~min}$. Lipid precursors ( $20 \mu \mathrm{M}$ PI or $20 \mu \mathrm{M}$ PIP (Sigma), solubilized in $0.1 \%$ Triton X-100/20 mM phosphate buffer $/ 1 \mathrm{mM}$ EGTA/1 mM DTT (pH 7.4), were added $15 \mathrm{~s}$ prior to phosphorylation, which was started by the addition of ATP, and lasted $1 \mathrm{~min}$. Incubations were performed under the following conditions: $7.5 \mu \mathrm{M}$ ATP, $2-3 \mu \mathrm{Ci}$ $\left[\gamma-{ }^{32} \mathrm{P}\right] \mathrm{ATP}$ (approximately $3000 \mathrm{Ci} / \mathrm{mmol}$. Amersham UK) $20 \mathrm{mM}$ phosphate buffer $\mathrm{pH} 7.4,10 \mathrm{mM} \mathrm{MgCl}$, $1 \mathrm{mM}$ EGTA, $1 \mathrm{mM}$ DTT, and $0.02 \%$ Triton X-100. The reaction was terminated, and the extraction and further analysis of the ${ }^{32} \mathrm{P}$ incorporated into PIP (PI kinase activity) and PIP $_{2}$ (PIP kinase activity) were performed as described elsewhere $[4,16]$. Protein determination was performed according to the method of Lowry et al. [18].

In the experiment presented here, we investigated whether the previously found lowered PI kinase activity in cytoplasmic preparations was also present in synaptosomes prepared from AD brains.

Table 1 shows the results of the protein determination of the homogenates and of the synaptosomal lysates prepared from both $\mathrm{AD}$ and control frontal cortex. In the homogenates, there was no difference in protein per $\mathrm{mg}$ tissue (wet weight) between AD and control. However, the synaptosomal lysates prepared from $\mathrm{AD}$ tissue showed a lower yield of protein per $\mathrm{mg}$ tissue than the synaptosomal lysates prepared from control tissue.

Fig. 1 shows that PI kinase activity in synaptosomal lysates prepared from $\mathrm{AD}$ brains was lower (approx. $30 \%$ ) than the PI kinase activity in synaptosomal lysates from control brains. PIP kinase activity was the same in preparations from $\mathrm{AD}$ and control brains.

Previously, Jolles et al. [14] reported a decrease in PI kinase activity in four neocortical regions of $\mathrm{AD}$ brains as compared to age-matched controls, where PIP kinase activity was not affected. In addition, Bothmer et al. [5] reported that type 1 PI kinase or PI 3-kinase was probably specifically involved in this AD-related decrease in PI kinase activity. In this study we investigated whether the

Table 1

Protein content of homogenates and synaptosomal fractions (yield), prepared from the frontal cortex of patients with Alzheimer's disease and controls

\begin{tabular}{lll}
\hline Preparation & Control & Alzheimer \\
\hline $\begin{array}{l}\text { Homogenate } \\
(\mu \mathrm{g} \text { prot./mg tissue })\end{array}$ & $97.6( \pm 3.8)$ & $91.2( \pm 5.7)$ \\
$\begin{array}{l}\text { Synaptosomes } \\
(\mu \mathrm{g} \text { prot./mg tissue })\end{array}$ & $1.30( \pm 0.09)$ & $0.89( \pm 0.10)^{*}$ \\
\hline
\end{tabular}

Brain samples were homogenized as described. In a small part of the homogenates $(1: 10)$ and a small part of the synaptosomal lysates, prepared from the homogenates, the protein content was measured ( $\mu \mathrm{g}$ protein/mg tissue). Statistical analysis was performed according to Student's $t$-test (two tailed). ${ }^{*} P<0.05$. 


\section{Phospholnositide klnase actlvitles in synaptosomes}

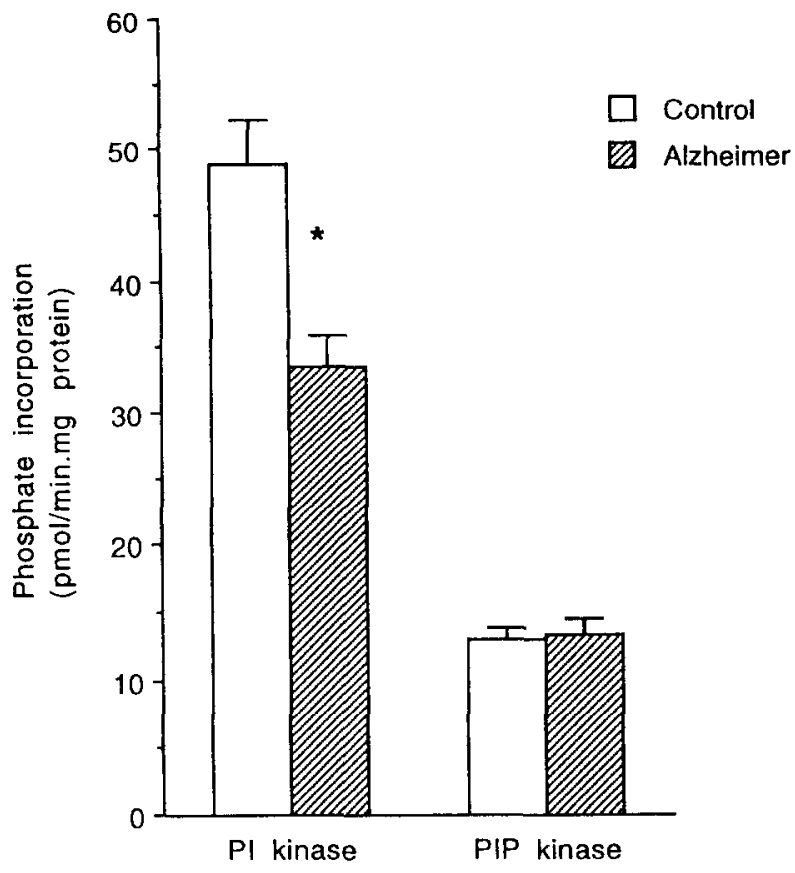

Fig. 1. Phosphatidylinositol (PI) kinase activity and phosphatidylinositol phosphate (PIP) kinase activity ( $\mathrm{pmol} / \mathrm{min} \cdot \mathrm{mg}$ protein) in synaptosomal lysates prepared from $\mathrm{AD}$ and control frontal cortex. Values shown are means ( \pm S.E.M.) of 6 control subjects and 6 AD subjects. Statistical analysis was performed according to Student's $t$-test (two tailed). ${ }^{*} P<0.01$.

decrease in PI kinase activity in AD brains could also be found in intact structures from AD brains. We used synaptosomes because Hardy et al. [12] have reported the successful preparation of metabolically active synaptosomes from postmortem human tissue. The yield of synaptosomes (expressed as the amount of synaptosomal protein per mg (wet weight) brain tissue) was rather low because the available brain material was frozen in liquid nitrogen, and it is known that fast freezing of whole tissue decreases the yield of synaptosomes [12]. The yield of synaptosomes (synaptosomal protein) from AD frontal cortex was lower than the yield from control frontal cortex. This is in agreement with the generally accepted finding of a loss of presynaptic terminals in the frontal, temporal and parietal cortices [20 and ref. therein, 13, 7].

After correction for the differences in protein, PI kinase activity in synaptosomal lysates prepared from $A D$ tissue was lower than that of control preparations. There was no difference in PIP kinase activity between AD and control synaptosomal lysate preparations. This is consistent with previous reports in which PIP kinase activity, in contrast to PI kinase activity, was also not affected [5, 14]. In one of these previous studies [5] a $20 \%$ decrease in PI kinase activity in membrane-protein preparations and a $70 \%$ decrease in PI kinase activity in cytosolic- protein preparations was found in $\mathrm{AD}$ brain as compared to controls. In the present study we find a $30 \%$ decrease in PI kinase activity in synaptosomal lysates which consists of both membrane and cytosolic protein. Because total (both types of PI kinase) PI kinase activity is to a greater extent present in the membrane [21], it can be argued that in the case there is a difference, it would be near the $20 \%$ decrease in PI kinase activity as has been found in the membrane protein preparation [5].

In conclusion, our results show a decrease in the amount of synaptosomal protein in $\mathrm{AD}$ frontal cortex as compared to control frontal cortex, which probably correlates with previously reported decreases in the number of synaptosomal contacts. Furthermore, PI kinase activity appears to be decreased in intact nerve endings from $\mathrm{AD}$ frontal cortex and could therefore be involved in the early events of the pathogenesis of AD. Because type 1 PI kinase is probably specifically affected in AD [5] and type $1 \mathrm{PI}$ kinase is involved in the regulation of cytoskeleton turnover [6], the decreased PI kinase activity could be related to the cellular pathology of $\mathrm{AD}$, as neurofibrillary tangles are partially composed of wrongly phosphorylated cytoskeletal components [11, 17].

[1] Berridge, M.J.. Inositol trisphosphate and diacylglycerol: Two interacting second messengers, Annu. Rev. Biochem., 56 (1987) 159 193.

[2] Booth, R. and Clark, J., A rapid method for the preparation of relatively pure metabolically competent synaptosomes, Biochem. J., 176 (1978) 365-370.

[3] Bothmer, J. and Jolles, J., Phosphoinositide metabolism, aging and Alzheimer's disease, Biochim. Biophys. Acta, 1225 (1994) 111124.

[4] Bothmer, J., Markerink, M. and Jolles, J., Phosphatidic acid and polyphosphoinositide formation in a broken cell preparation from rat brain: effect of different incubation conditions, Neurochem. Int., 17 (1990) 27-33.

[5] Bothmer, J., Markerink, M. and Jolles, J., Evidence for a selective decrease in type 1 phosphatidylinositol kinase activity in brains of patients with Alzheimer's disease, Dementia, 5 (1994) 6-11.

[6] Carpenter, C. and Cantley, P., Phosphoinositide kinases, Biochemistry, 29 (1990) 11147-11156.

[7] DeKosky, S. and Scheff, S., Synapse loss in frontal cortex biopsies in Alzheimer's disease: correlation with cognitive severity. Ann. Neurol., 27 (1990) 457-464.

[8] Downes, C.P. and Macphee, C.H., myo-Inositol metabolites as cellular signals, Eur. J. Biochem., 193 (1990) 1-18.

[9] Fowler, C., O'Neill, C., Garlind, A. and Cowburn, R., Alzheimer's disease: Is there a problem beyond recognition?, Trends Pharmacol. Sci., 11 (1990) $183-184$.

[10] Grundke-Iqbal, I., Iqbal, K., Tung, Y.-C., Quinlan, M., Wisniewski, H. and Binder, L., Abnormal phosphorylation of the microtubule-associated protein $\tau$ (tau) in Alzheimer cytoskeletal pathology, Proc. Natl. Acad. Sci. USA, 83 (1986) 4913-4917.

[11] Hanger, D., Brion, J.-P., Gallo, J.-M., Cairns, N., Luthert, P. and Anderton, B. Tau in Alzheimer's disease and Down's syndrome is insoluble and abnormally phosphorylated, Biochem. J., 275 (1991) 99-104.

[12] Hardy, J. Dodd, P. Oakley, A., Perry, R., Edwardson, J. and Kidd, A., Metabolically active sy-naptosomes can be prepared from frozen rat and human brain, J. Neurochem., 40 (1983) 608.

[13] Honer, W., Dickson, D., Gleeson, J. and Davies, P., Regional 
synaptic pathology in Alzheimer's disease, Neurobiol. Aging, 13 (1992) 375-382.

[14] Jolles, J., Bothmer, J., Markerink, M. and Ravid, R., Phosphatidylinositol kinase is reduced in Alzheimer's disease, J. Neurochem., 58 (1992) 2326-2329.

[15] Jolles, J., Schrama, L.H. and Gispen, W.H., Calcium-dependent turnover of brain poly-phosphoinositides in vitro after prelabelling in vivo, Biochim. Biophys. Acta, 666 (1981) 90-98.

[16] Jolles, J., Zwiers, H., Dekker, A., Wirtz, K. and Gispen, W., Corticotropin-(1-24)-tetracosapeptide affects protein phosphorylation and polyphosphoinositide metabolism in rat brain, Biochem. J., 194 (1981) 283-291.

[17] Kosik, K., Alzheimer's plaques and tangles: advances on both fronts, Trends Neurosci., 14 (1991) 218-219.

[18] Lowry, O., Rosebrough, N., Farr, and Randall, R.J., Protein measurements with the folin phenol reagent, J. Biol. Chem., 193 (1951) 265-275.

[19] Martelli, A.M., Gilmour, R.S., Neri, L.M., Manzoli, L., Corps, A.N. and Cocco, L., Mitogen-stimulated events in nuclei of Swiss $3 T 3$ cells. Evidence for a direct link between changes of inositol lipids, protein kinase $C$ requirement and the onset of DNA synthesis, FEBS Lett., 283 (1991) 243-246.

[20] Masliah, E., Ellisman, M., Carragher, B., Mallory, M., Young, S., Hansen, L., DeTeresa, R. and Terry, R., Three-dimensional analysis of the relationship between synaptic pathology and neuropil threads in Alzheimer disease, J. Neuropathol. Exp. Neurol., 51 (1992) 404414.

[21] Saltiel, A.R., Fox, J.A., Sherline, P., Sahyoun, N. and Cuatrecasas, P., Purification of phosphatidylinositol kinase from bovine brain myelin, Biochem. J., 241 (1987) 759-763.

[22] Shimohama, S., Homma, Y., Suenaga, T., Fujimoto, S., Taniguchi, T., Araki, W., Yamaoka, Y., Takenawa, T. and Kimura, J., Aberrant accumulation of phospholipase C-delta in Alzheimer brains, Am. J. Pathol., 139 (1991) 737--742.

[23] Stokes, C. and Hawthorne, J., Reduced phosphoinositide concentrations in anterior temporal cortex of Alzheimer-diseased brains, J. Neurochem., 48 (1987) 1018-1021.

[24] Young, L.T., Kish, S.J., Li, P.P. and Warsh, J.J., Decreased brain $\left[{ }^{3} \mathrm{H}\right]$ inositol 1,4,5-trisphosphate binding in Alzheimer's disease, Neurosci. Lett., 94 (1988) 192-202. 